The knisor of $x$

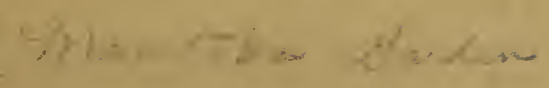

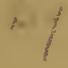

Hinns. evere

$$
\begin{aligned}
& \text { Fsiala } \\
& 1970 \\
& 908
\end{aligned}
$$





\section{THE BIRDS OF A MANITOBA GARDEN}

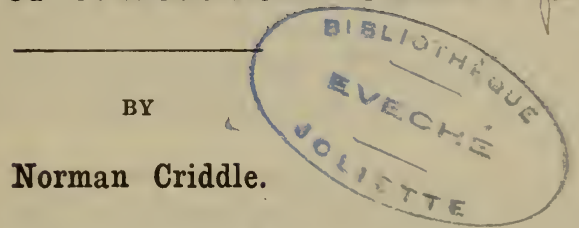

$\mathrm{T}$ this article the author has shown the beauty of a flower and bird garden combined. Our insectivorous birds are worth protecting and their beauty of song and colour would improve your garden. Much valuable bird life is being saved to-day by the enforcement of the Migratory Birds Convention Act, which is administered by the Dominion Parks Branch, Department of the Interior, Ottawa. You can help by protecting the birds on your premises.

The garden to which this article refers, is a country one. It was originally an old cattle yard, situated in a very sandy locality upon a hill. Whien first ploughed and prepared for its present use, the land was laid out to include an area of approximately 270 feet by 250 feet. Within this space, but around the edges, were planted spruce intermixed with poplar, elm and ash, while inside of these, various shrubs, such as lilac, caragana, and honeysuckle, several of which are berry bearing. These plants have all grown well so that there is now sufficient shelter to accommodate even such shade-loving birds as the Catbird. The middle portion of the garden is devoted to herbaceous plants, many of which represent crosses or "new creations," originated by my brother Stuart. The whole area is surrounded by a fence built to keep out cattle, but not poultry or dogs. Cats being recognized as one of the chief enemies of birds, are rigidly eliminated.

The bird visitors of this garden are naturally numerous, especially during the seasons of migration. At these times the underbrush is flooded with such species as Tree Sparrows, White-throats, Harris' 19071 
Sparrow and Juncos; to say nothing of a host of others occurring more sparingly. Most of these are but passing visitors, howerer, whereas I intend, in this article, to confine myself to breeding birds which have actually made their homes within, or upon the fence. I say upon the fence advisedly because it is there that are placed several

- boxes with holes of appropriate size to accommodate various feathered friends.

The boxes proved a success from the start. One near the gate, a square one about a foot in height, and four by five inches inside, has been the home of no less than three species. The first to take possession were a pair of Bluebirds, and who could wish for more beautiful tenants. The male came finst upon the scene and sang his quaint but sweet song for at least a week before his less brightly coloured mate arrived. She made herself at home immediately and was very soon carting in a variety of grass stems, bark and softer things for nest construction. Her husband lent a beak now and then, he also brought an odd morsel of food in the form of a grasshopper or caterpillar, but as a rule he seemed to feel that his duty lay in singing and driving away intrudens, rather than in nest building. He proved an adept as a sentry and, astonishing as it may seem, was as successful at driving away House Sparrows as he was with less pugnaceous offenders. Bluebirds, while they often breed in the vicinity of human habitation, are, nevertheless, of a naturally shy disposition. It is well, therefore, not to disturb them more than is necessary, otherwise they may desert the nest as well as the vicinity.

It was not long before a clutch of light-blue eggs had been laid and in due course six young were clamouring for food. The next few weeks were busy ones for the parents, especially for the female, and a very large number of insects were collected for food. In due course the young left the nest and not so very long afterwards a second brood was being reared. This, like the last was safely brought to maturity and as the shades of approaching winter drew near, the birds departed for their southern home.

The Bluebirds were late in arriving the next year, having apparently attempted to nest elsewhere. They soon took to the old box, but 
had hardly done so before a pair of new comers arrived. These were Mountain Bluebirds, which differ from the others in being lighter blue and having blue instead of reddish upon the breast. The new arrivals decided that they too, preferred the old box and in consequence some severe fighting took place for possession. Eventually, however, the old pair were driven out and the newcomers occupied the premises. Fortunately another box was available outside the limits of the garden and in this the old inhabitants reared their family in peace.

The life of the new arrivals was not without misfortune. When the young were about a week old the beautiful male fell a victim to a Cooper's Hawk and the female was, therefore, left to do the work of both. This she continued to do with marked success. Later she was visited by a new courtier, but since he refused to labour on behalf of the family, his courting met with scant success. He remained, however, in the vicinity and when the family, after emerging from their box, were resting together upon the nearby trees, the new male formed part of their company.

The only other box inhabitants were a pair of House Wrens, true they had with the usual wren industry, blocked various other boxes with sticks, but as this was one of their usual tactics to prevent near neighbours, I freed the boxes from their encumbrances. One could write pages about wrens, their cheerfulness, the house-cleaning of the male who prepared for his mate's coming, and a host of other habits, all of which must endear these little birds to any observant person. Wrens are among the most useful of a garden's inhabitants and do much to free the plants of the insect pests that infest them. Wrens will nest in nearly anything from a coat pocket to an old hat, but they prefer a box which has a small entrance. This need not be cleaned, as the birds will see to that themselves.

Since the central area of the garden is small it is not to be expected that many ground-loving birds would make their homes within. Nevertheless we have had two species do so. Of these none were more welcome than a pair of Prairie Horned Larks. These birds, as is well known are first to brave our winter weather and move up from the 
south to announce the coming spring. The Prairie Horned Lark is a very early arrival in Manitoba and can be looked for, on an average, about the 20th of February. By the end of March numbers are nesting and slightly more than a month later, nearly mature young can be found. There are certainly thiree broods in a season and, at times, probably a fourth. The horned larks should be a favourite with every country dweller. Boldly braving the snows and cheerful in the midst of them, he comes back when others would find it both cold and difficult to secure food.

The first nest we discovered in the garden was found by accident in which the whole structure was raked from its foundation before being noticed. Fortunately no damage had been done and the nest was soon in place again. As this nest was situated on the edge of a flower bed, the possessors were naturally obliged to put up with numerous visits from the gardener as a result of which they soon became very tame. We were able to observe the female fit herself over the eggs or young and later watch both birds feed and tend the nestlings. Thus it was discovered that fully 85 per cent of the food consisted of insects of which by far the greater proportion were cutworms, insects which are known to be among the gardener's worst enemies. In due course the young left the nest but they remained in the vicinity for a considerable time afterwards, while the parents reared a fresh brood near by, but outside the boundaries of the garden.

The other ground nesting tenant, to which I refer, was the Vesper Sparrow. It had graced our garden twice with its presence. On the second occasion the pair selected the base of a pretty clump of Indian pinks to build their nest and had as a foreground pansies of many colours. The Vesper bird is inconspicuous in its dress of grey, but makes up for this by its sweet song which, in spring, is repeated by so many individuals that the whole country-side rings with their music. Two broods are the Vesper average. The birds come to us from the south about the middle of April and depart for their winter home in late September or early October.

One of the yearly visitors of our garden is the Chipping Sparrow. Two or three pairs always make it their home, while others nest 
around the house. The Chipping Sparrow is one of those species that has actually been brought to the vicinity by the planting of evergreens. Previously to the planting of such trees they had been common enough in the "Spruce W.oods Reserve," but had not nested near by.

There is something in the song of a Chippy that recalls the sultriness of summer and the shade amidst the heat. The song is a succession of rapidly uttered, similar notes which, at a short distance, seem not unlike the deep breathing of a sleeper. I have listened to these many times during the day-time, also at the time when the shadows of night are giving place to the light of day, and the resemblance is nearly always there.

The Chippy is one of our smallest sparrows, it has a reddish-brown crown like the Tree Sparrow, which the bird resembles in other respects. It has, however, a plain white breast, instead of the little dark patch characteristic of the Tree Sparrow. The nest is a wellmade structure, neatly lined with fine grass and hair, when the latter is available. Chipping Sparrows are double-brooded. They feed their young on various forms of insect life, picked up amid the low trees and shrubs.

Clay-coloured Sparrows resemble the Chippy in size, but are lighter and lack the brown crown. They inhabit low shrubs and usually build close to the ground. The nest is constructed of coarse grass stems with a rather sparse lining of finer grass or hair. The eggs, like those of the Chippy, are blue with a ring of purplish markings around the wider end.

We generally have but one pair of Clay-colours in the garden, due in part, I believe, to their not getting on with the Chippies. The song is grasshopper-like and may be recalled by the syllables-zee-zee, often repated several times. The bird is double-brooded.

We have had Kingbirds nesting with us twice and they proved useful allies in driving away a casual hawk or crow, but if they thus conferred an unintentional benefit on the rest of the feathered inhabitants, they were equally tyrannical to those they had protected, and the chase after a Chippy seemed to afford them as much amusement 
as riding upon the back of a crow. Thus I sometimes feel that a Kingbird is not the most desired tenant, though we make no exceptions in our welcome to all.

One of the irregular summer residents of the garden is the Cedarbird or Cherry-waxwing. A beautiful fawn-coloured bird with a well. marked crest. There are few that can vie with the Waxwing in soft beauty of plumage, but they are not singers, and their only utterances are soft, whispery notes, which, however, are unlike any other summer bird. The species usually comes in flocks and gradually pair off as the season advances. Our garden visitors selected spruce trees for their nesting sites and placed the structure well back amid the branches, some six feet from the ground. Here they reared their young upon insects and small fruits without in any way interfering with the other birds.

I have often thought that few of our feathered friends could surpass the Catbird for singing qualities. There is something quaint and yet sweet in the bird's notes, and a softness which associates the singer with the shady haunts it loves. The Catbird is at its best soon after daylight, when from some perch above the shadows he pours forth the song for which he is becoming famous. The bird is also a mimic of note, and can imitate any bird from a Meadowlark to a Least Flycatcher.

Catbirds are inhabitants of thick underbrush and the mixed shrubs made up of lilac and honeysuckle prove very attractive. Here it is that they build their nest of sticks and bark and later deposit the beautiful deep green-blue eggs. These birds get their name from the weird, supposedly cat-like sounds which they utter, especially when disturbed. We have had a pair nesting in our garden for the last four years.

Robins are constant visitors to the garden. They come, to begin with, for the sake of the berries, but do not always nest within the borders of the fence. They have, however, done so twice. On the first occasion the nest met with a disaster, the young being pulled out and devoured by a cat. On the second attempt the birds were more successful and managed to rear their young to maturity. 
Robins are models of domestic companionship, for not only do both share in the nest building, but the male also assists in feeding the young and otherwise attends to them.

Like most birds the Robin is at his best soon after sunrise, and it is then that he pours forth the loud, cheerful song with which even city dwellers should be familiar. The males return to us from the south early in April and are followed by the females about two weeks later. These birds usually rear two broods in a season, and frequently do so in the same nest.

Such are our garden tenants of to-day. As time goes on and the trees grow, we hope to attract others, which would add to the pleasure and interest which our present feathered friends have given us.

Copies of pamphlets, issued in the interest of bird protection and of the Migratory Birds Convention Act and Regulations, may be obtained from the Commissioner, Dominion Parks Branch, Department of the Interior, Ottawa.

M.B. L 12, 1920. 


\section{The EDITH and LORNE PIERCE COLLECTION of CANADIANA}

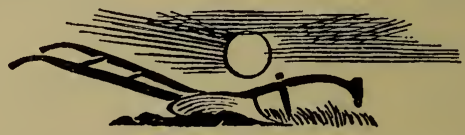

Queen's University at Kingston 


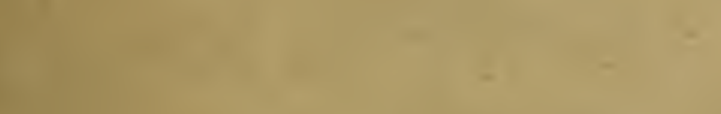

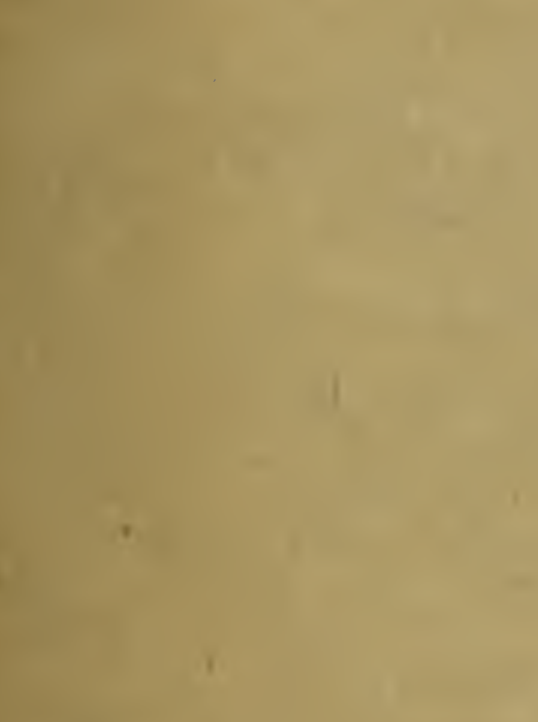


